\title{
The most extensive oil spill registered in tropical oceans (Brazil): the balance sheet of a disaster
}

\author{
Marcelo Oliveira Soares ${ }^{1,2}$ (1) . Carlos Eduardo Peres Teixeira ${ }^{1} \cdot$ Luis Ernesto Arruda Bezerra $^{1}$. \\ Emanuelle Fontenele Rabelo ${ }^{3} \cdot$ Italo Braga Castro $^{4} \cdot$ Rivelino Martins Cavalcante $^{1}$
}

Received: 28 July 2021 / Accepted: 13 January 2022 / Published online: 21 January 2022

(c) The Author(s), under exclusive licence to Springer-Verlag GmbH Germany, part of Springer Nature 2022

\begin{abstract}
This article presents a synthesis of information about the massive oil spill in Brazil (2019/2020). The event affected 11 states; however, the majority of the oil residue was collected ( 5380 tons) near nine states $(99.8 \%)$ in northeastern Brazil. This spill was not the largest in volume (between $5000 \mathrm{~m}^{3}$ and $12,000 \mathrm{~m}^{3}$ ) recorded in tropical oceans, but it was the most extensive $(2890 \mathrm{~km})$. This spill develops an overwashed tar that remains mostly in the undersurface drift (non-floating oil plume) below $17 \mathrm{~m}$ of depth while on the continental shelf. Ten ecosystems were impacted, with potentially more severe effects in mangroves and seagrasses. Certain negative effects are still understudied, such as effects on tropical reefs and rhodolith beds. A total of 57 protected areas in seven management categories were affected, most of which $(60 \%)$ were characterized as multiple-use regions. The spill affected at least 34 threatened species, with impacts detected on plankton and benthic communities. Acute impacts were reported on echinoderms, coral symbionts, polychaetes, and sponges with evidence of oil ingestion. Socioeconomic impacts were detected in food security, public health, lodging, gender equality, tourism, and fishing, with reduced sales, prices, tourist attractiveness, gross domestic product, and employment. Moreover, chemical contamination was detected in some states by toxic metals ( $\mathrm{Hg}, \mathrm{As}, \mathrm{Cd}, \mathrm{Pb}$, and $\mathrm{Zn}$ ) and polycyclic aromatic hydrocarbons (acenaphthalene, fluoranthene, fluorene, naphthalene, and phenanthrene). This summary aims to aid in the design of science-based strategies to understand the impacts and develop strategies for the most extensive spill observed in tropical oceans.
\end{abstract}

Keywords Mysterious oil spill $\cdot$ South Atlantic $\cdot$ Coral reefs $\cdot$ Mangroves $\cdot$ Marine protected areas

\section{Introduction: the underrated and mysterious oil spill in the South Atlantic Ocean}

Oil spills generate short- and long-term impacts that require science-based policy to mitigate damage and enable recovery of the affected areas (Beyer et al. 2016; Nunes et al.

Responsible Editor: Philippe Garrigue

Marcelo Oliveira Soares

marcelosoares@ufc.br

1 Instituto de Ciências Do Mar (LABOMAR), Universidade Federal Do Ceará (UFC), Fortaleza, Brazil

2 Reef Systems Group, Leibniz Center for Tropical Marine Research (ZMT), Bremen, Germany

3 Universidade Federal Rural Do Semi Árido (UFERSA), Mossoró, Brazil

4 Instituto Do Mar, Universidade Federal de São Paulo (UNIFESP), Santos, Brazil
2021). Recently (2019/2020), the Brazilian coast endured a mysterious oil spill that affected 11 states and approximately $2890 \mathrm{~km}$ of its tropical coastline (Escobar 2019; Disner and Torres 2020; Magris and Giarrizzo 2020; Soares et al. 2020a, b). An aspect of this event that has been widely recognized in the scientific literature is the late, weak, and uncoordinated action of the Brazilian federal government in combating social, public health, and environmental emergencies (Brum et al. 2020; Goncalves et al. 2020; Pena et al. 2020; Soares et al. 2020a, b; Sissini et al. 2020). Scientific denialism, fake news, misinformation, and reductions in scientific and environmental budgets were factors affecting the efficiency of national actions to mitigate and compensate for the impacts of the spill (Barbosa et al. 2021; Goncalves et al. 2020; Lemos et al. 2020; Soares et al. 2020a, b). Some Brazilian States, after experienced some difficulties, have exhibited integrated coordination with non-governmental organizations, the military, civil society, universities, and Brazilian municipalities and searched, as much as possible, 
to provide science-based actions during the disaster. The geographic extension of the incident and the social, economic, and ecological impacts standout the 2019/2020 event as the worst environmental disaster in Brazilian history and the most extensive ever recorded in the tropical oceans (Magalhães et al. 2021; Soares et al. 2020a, b).

Although information regarding this mysterious oil spill has grown rapidly between 2019 and 2021, the data collected remains largely unknown to administrative agencies, stakeholders, non-governmental organizations (NGOs), governments, and the private sector. It is increasingly difficult for specialists and the general public to stay current with the expanding volume of information published, despite significant concern by the media, society, and other stakeholders regarding the ecological and socioeconomic impacts of this large-scale event. Moreover, the government's actions considering the discussions regarding the remaining fossil fuel exploitation and potential impact on ocean biodiversity and climate change are necessary due to the COP-26 agreements. In this framework, a cohesive review is crucial and timely.

Therefore, this discussion article seeks to present synthetic knowledge in order to improve awareness of the impacts of oil spills on the SW Atlantic Ocean. This summary aims to aid in the design of science-based strategies to understand the impacts and develop remediation strategies for the most extensive oil spill observed in tropical oceans. First, we discuss the origin and source of the spill, followed by the ecological and socioeconomic impacts of this disaster. Finally, we discuss the core questions for future research and government actions.

\section{Methodology}

A qualitative analysis of the published literature on Brazilian oil spills was performed in two steps. First, the terms "oil spill," "mysterious oil spill" AND/OR "Brazil," “2019/2020," "2019," "South Atlantic," "Southwestern Atlantic," "Crude oil," "Environmental disaster," "oil spilled," "Brazilian oil spill" were searched in academic online search engines (Google Scholar, Science Direct, Web of Science, and Scopus). Second, the results of the literature search were sorted according to four main topics: oil and source of origin, ecological impacts (ecosystems and species), and socioeconomic impacts. No time-scale boundaries were imposed. To identify articles missed during the first step of selection, we also consulted the references cited in each relevant article and review (Goncalves et al. 2020; Lourenço et al. 2020; Magris and Giarrizzo 2020; Soares et al. 2020a, b; Estevo et al. 2021; Campelo et al. 2021; Craveiro et al. 2021; Soares et al. 2021; Zacharias et al. 2021a, b). All papers with an English title and abstract were manually screened for content, and the remaining papers were downloaded and examined individually. A total of 33 published articles (2019-2021) met our established criteria. For analyses of the quantities of oil collected in the Brazilian states and the marine protected areas affected by the spill, the data were extracted from IBAMA (2019) and Soares et al. (2020b).

\section{Oil and source of origin: an unsolved puzzle}

The regions mainly affected ( $99.88 \%$ of the oil spilled) were the nine states in the Northeast of Brazil which have an economy (e.g., services, aquaculture, and tourism) focused on the coastal region (eight nearshore state capitals), traditional communities highly vulnerable to disasters such as artisanal fishers, maroons (quilombolas), and indigenous people, as well as the highest levels of social inequality in the country (Câmara et al. 2021; Mendes et al. 2021).

The oil spill first arrived along the coast in August 2019, with the last reported large slicks occurring during the COVID-19 (Sars-Cov-2 virus) pandemic in June 2020 (Magalhães et al. 2021) and July 2021 (Bahia state). The greatest incidence of events occurred between August 2019 and December 2019, with the largest oil volume and number of sites ( 998) affected (Soares et al. 2020b). However, after more than 2 years, it is still possible to find petroleum residue in sandstone reefs (Fig. 1) or on the dunes. This diffuse source of hydrocarbons is difficult to remediate and may be neglected, causing it to affect the environment for an indeterminate time.

5379 tons of oil residue (usually mixed with beach sand) was collected on the Brazilian tropical coastline over this period, particularly in the Alagoas and Pernambuco states ( $78 \%$ of oil collected). The first work after the accident showed considerable levels of PAHs such as: naphthalene, phenanthrene, fluoranthene, fluorene, and acenaphthalene in seawater, fish, and massunins (bivalve). On the other hand, metals such as $\mathrm{Hg}, \mathrm{As}, \mathrm{Cd}, \mathrm{Pb}$, and $\mathrm{Zn}$ were found only in seawater, at levels above those recommended in the Brazilian resolution (Soares et al. 2021).

Recent analyses have indicated that the oil found along the entire Brazilian coast has the same origin because of its similar characteristics (solid tar, denser than seawater, with stable or meso-stable emulsion formation from weathering processes) (Lourenço et al. 2020; Kelvin et al. 2021). There is no scientific literature modeling oil transport, but the most probable spill location is $\sim 700 \mathrm{~km}$ off the Brazilian coast (Lessa et al. 2021, Soares et al. 2020b; Zacharias et al. 2021a). The oil subsequently moved closer to the continental shelf by the force of the southern branch of the South Equatorial Current and was guided northward by the North Brazil Current and then southward by the Brazil Current. Coastal upwelling conditions advected the oil from the slope onto the outer and mid-shelf below $17 \mathrm{~m}$ depth in some locations as wave action brought it to the coast (Lessa et al. 2021). 


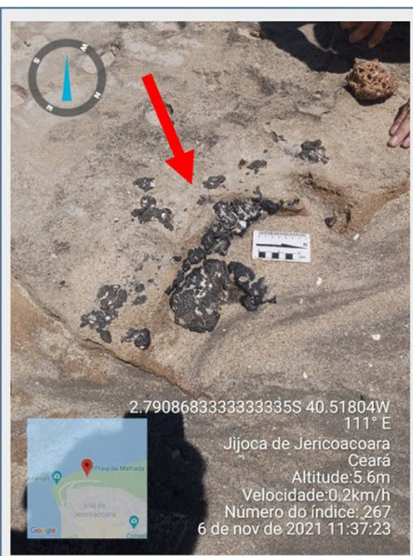

Jericoacoara beach

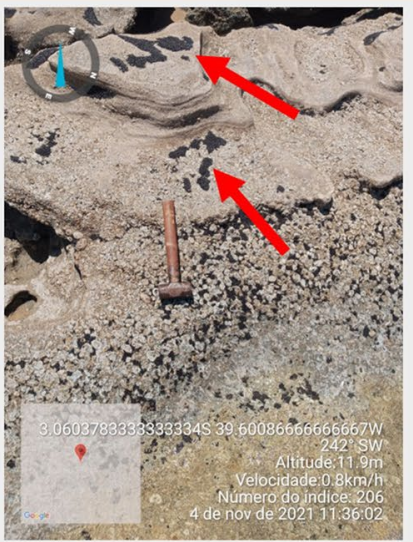

Caetanos beach

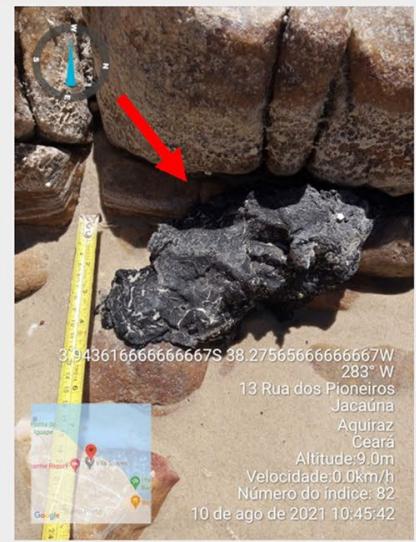

Iguape beach

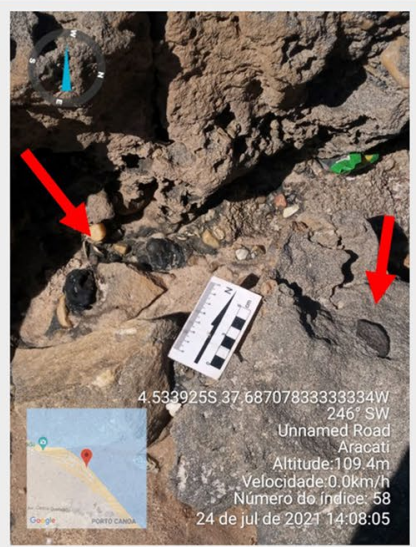

Canoa Quebrada beach

Fig. 1 Four present-day (2021) intertidal sandstone reefs at Ceará coast (northeastern Brazil). Even after 2 years of oil arrival (2019), the oil residue (indicated by arrow) remains still impregnated on the rocks. Photographs from July to November (2021)

The original hypotheses regarding the origin of this mysterious oil spill were as follows: (1) It came from natural sources (e.g., asphalt seep sites) in Brazil or Africa; (2) the oil spilled from platforms in Brazil or Africa; (3) the oil spilled (intentionally or not) from ships in transit off the Brazilian coast; and (4) the oil came from shipwrecks (recent or old) (Escobar 2019; Soares et al. 2020a, b). Geochemical and biomarker analyses of sedimentary basins indicated that the oil originated from Venezuelan sedimentary oil basins (e.g., Ayacucho oil, from Naricual Formation in Venezeluan Eastern basin); therefore, hypotheses 1 and 2 were discarded (Lourenço et al. 2020; Oliveira et al. 2020; Carregosa et al. 2021; Zacharias et al. 2021a, b). Currently, hypotheses 3 and 4 remain with ongoing and intense debate.

The Federal Police concluded the investigation into the mysterious oil and named the company, the commander and the chief engineer of a Greek-flagged ship named responsible for dumping the material on the Brazilian coast. In its final report, the police calculate minimum damage of $\mathrm{R} \$ 188$ million for the federal government and also prepare a report on the total amount that will consider other factors such as damage to fishing communities and tourism (Federal Police 2021). Recently, Zacharias et al. (2021a) used weathering equations from the Spill, Transport, and Fate Model to assess this disaster. They concluded that the spilled volume was considerably smaller than that of a full tanker (5000-12,500 $\left.\mathrm{m}^{3}\right)$ and suggested that the spill may have occurred due to buoyancy problems on the tanker (hull rupture or engine failure), causing it to continuously release its cargo. They provided evidence of leaking (or dumping) from an unidentified vessel of a size between Panamax and Suezmax carrying Venezuelan oil. In the scenario of a slow leak, a tanker could travel long distances discharging small volumes of oil below the water surface, unseen by Brazilian and international authorities (Zacharias et al. 2021a, b).

Another possible hypothesis is leakage from sunken vessels (bottom-puff spill) due to corrosion that exists in the oceanic region (outside the Economic-Exclusive Zone-EEZ), mainly from the last decades, implying that natural corrosion on iron structures can cause leakage (Johnson et al. 2006). In the last decade, shipwrecks have been recognized as a threat to the marine environment due to oil and other materials and the uncertainty of the probability and time of release (Landquist et al. 2013; Ventikos et al. 2013). More than 500 shipwrecks from World War II are known to exist in the South Atlantic Ocean, including some oil tankers with Venezuelan oil, but their environmental risk and vulnerability (Monteiro et al. 2020) have not been assessed, casting them as unheeded time bombs for future oil spills (Soares et al. 2020c). The lack of transparency from the Brazilian Federal Government in assessing this complex puzzle and the absence of a unified national boat surveillance system and vessel tracking strategy along the extensive EEZ (5.7 million $\mathrm{km}^{2}$ ) has made it difficult to assess both remaining hypotheses (3 and 4) (Soares et al. 2020a, b; Zacharias et al. $2021 \mathrm{a}, \mathrm{b})$. In addition, the oil traveled for a long distance in subsurfaces suffering severe weathering before reaching the sandy beaches and other regions of the Brazilian shore (Oliveira et al. 2020).

Zacharias et al. (2021b) tested four different hypotheses about this mysterious and extensive oil spill. Three of the hypotheses (superficial oil slick, bottom-puff spill, and on-route spill) could not represent the spreading along the entire Brazilian coast seen in 2019 (Soares et al. 2020a, b, c), according to their simulations. These results indicate that the under-surface drift was more important in the extensive spread than a possible initial distribution of the oil by the 
vessel movement (Zacharias et al. 2021b). This does not imply that the oil spill occurred with the ship stopped, or in only one site; rather, it indicates a new spill scenario along the tanker's path with non-floating oil could be included. In this scenario (non-floating oil plume), the oil tanker was partially loaded with Venezuelan Orimulsion or another non-floating oil (complex industrial mixture), or deliberate application of dispersants to hide the source of the spill (Zacharias et al. 2021b). In other words, the spill develops an overwashed tar that remains mostly in the undersurface drift (Lessa et al. 2021; Zacharias et al. 2021b). Therefore, the common methods of remote sensing (Rajendran et al. 2021) did not help in determining the source area of the oil spill, which makes a detailed analysis of these hypotheses difficult.

\section{Ecological impacts: protected areas, tropical ecosystems, and species}

The oil spill affected at least 57 coastal and marine protected areas (MPAs) on the Brazilian coast (Ladle et al. 2020; Soares et al. 2020a, b). The Conservation Units (Unidades de Conservação - UC in Portuguese) are protected areas that are included in two management groups in Brazil: strictly protected areas (or no-take/full protection) and sustainable-use protected areas (or direct and multiple uses) (Table 1). This oil spill affected at least seven distinct categories of MPAs, three of full protection: Biological Reserve, National Park, and Wildlife Refuge; and four Multiple-Use areas: Area of Ecological Interest, Private Natural Heritage Reserve, Environmental Protection Area, and Extractive Reserve (Soares et al. 2020b). Most of the affected
MPAs were environmentally protected areas (34), followed by extractive reserves (9), parks (8), private natural heritage reserves (3), biological reserves (1), areas of ecological interest (1), and wildlife refuges (1). However, it is important to note that these numbers are likely underestimated because they were collected approximately a year prior to this review (Soares et al. 2020b) and other affected MPAs may be discovered to have been impacted by oil contamination with future research. It is important to highlight that pollution is one of the five main contemporary threats to biodiversity. In this regard, two review studies exhaustively assessed contamination by polycyclic aromatic hydrocarbons-PAH (Nunes et al. 2021) and tributyltin (Castro et al. 2021a, b) throughout Latin America and found 53 and 36 contaminated MPAs over the last decade. Thus, the high number of MPAs affected by this single and extensive oil spill (57) indicates that environmental impacts are difficult to overcome in the ocean basin. Recent analyses have indicated that the seawater, fishes, and bivalves presented the main PAH: naphthalene, phenanthrene, fluoranthene, fluorene, and acenaphthalene. In this regard, naphthalene was the major contributor to the total concentration of $16 \mathrm{PAH}$ analyzed (Soares et al. 2021).

The oil spill affected at least 10 different tropical ecosystems, particularly estuarine water bodies $\left(4929.74 \mathrm{~km}^{2}\right.$ of the area affected), followed by mangrove forests $\left(489.83 \mathrm{~km}^{2}\right)$, seagrass meadows $\left(324.77 \mathrm{~km}^{2}\right)$, beaches $\left(185.3 \mathrm{~km}^{2}\right)$, tidal flats $\left(63.64 \mathrm{~km}^{2}\right)$, intertidal hard bottoms such as sandstone reefs (Fig. 1) $\left(45.95 \mathrm{~km}^{2}\right.$ ), and shallow-water coral reefs $\left(9.69 \mathrm{~km}^{2}\right.$ ) (Magris and Tommaso 2020). Other tropical ecosystems that were not mapped but presented qualitative impacts were rhodolith beds (Sissini et al. 2020), mesophotic reefs, sand dunes, and shrub vegetation areas in sandbanks
Table 1 Collected oil residue (metric tons), relative frequency $(\%)$, and numbers of coastal and marine protected areas (MPAs) affected by the oil spill in each Brazilian state

\begin{tabular}{lcll}
\hline Brazilian state & $\begin{array}{l}\text { Collected oil residue } \\
\text { (tons) }\end{array}$ & $\begin{array}{l}\text { Relative oil amount } \\
\text { removed ( \%) }\end{array}$ & $\begin{array}{l}\text { Numbers of MPAs } \\
\text { affected by the spill }\end{array}$ \\
\hline Alagoas & 2564.58 & $47.67 \%$ & 4 \\
Pernambuco & 1676.26 & $31.16 \%$ & 7 \\
Sergipe & 569.35 & $10.58 \%$ & 2 \\
Bahia & 459.49 & $8.54 \%$ & 15 \\
Ceará & 39.76 & $0.74 \%$ & 8 \\
Rio Grande do Norte & 35.18 & $0.65 \%$ & 4 \\
Maranhão & 13.69 & $0.25 \%$ & 5 \\
Piauí & 10.46 & $0.19 \%$ & 1 \\
Espirito Santo & 6.26 & $0.12 \%$ & - \\
Offshore marine area (Exclusive & 3.88 & $0.07 \%$ & 5 \\
Economic Zone) & & & 1 \\
Paraíba & 0.85 & $0.02 \%$ & 57 \\
Rio de Janeiro & 0.01 & $0.01 \%$ & \\
TOTAL & 5379.76 & $100 \%$ & \\
\hline
\end{tabular}

Source: compiled from IBAMA (2019). Data for Brazilian states and offshore marine areas during the event in 2019/2020 
(restingas in Portuguese) (Soares et al. 2020b). However, we still do not know the impact on mesophotic reefs or rhodolith beds (Sissini et al. 2020). Considering the denser oil deposited in the Brazilian carbonate continental shelf during the spill, we can expect negative impacts on these deeper communities. These quantitative footprints show the extent to which the oil spill impacted distinct landscapes and seascapes. However, it should be noted that such affected areas are likely underestimated due to the lack of high-resolution mapping (1:10,000 scale) of the Brazilian ecosystems along the extensive tropical coastline (Magalhães et al. 2021). Among these affected areas, three are of special ecological concern: (i) coastal ecosystems between the states of Rio Grande do Norte and Alagoas (e.g., including the largest nearshore Brazilian MPA: Coral Coast) because of the large amount of oil spilled in that region (Table 1); (ii) habitats within and around the city of Salvador (Bahia state), and (iii) marine habitats on the Abrolhos Bank and in southern Bahia (the richest reef complex in the SW Atlantic with high levels of coral endemism) (Magris and Giarrizzo 2020; Miranda et al. 2020; Soares et al. 2020b; Magalhães et al. 2021).

Furthermore, the affected areas shelter at least 34 threatened species which are vulnerable to the ongoing oil spill impacts along the Brazilian coast, including 11 elasmobranchs (e.g., Carcharhinus perezi and Carcharhinus porosus, Mobula thurstoni and Mobula hypostoma, Pristis pristis and Pristis pectinata), 10 fishes (e.g., Epinephelus itajara, Hippocampus reidi, Megalops atlanticus, Scarus trispinosus, and Scarus zelindae), 5 invertebrates (endemic corals Mussismilia harttii and Mussismilia braziliensis, seastars Luidia senegalensis and Oreaster reticulatus, and the mollusk Lobatus goliath), 4 migratory birds (i.e., Calidris canutus, Calidris pusilla, Limnodromus griseus, and Charadrius wilsonia), 3 marine turtles (Eretmochelys imbricata, Chelonia mydas, and Lepidochelys olivacea), and 2 marine mammals (dolphin Sotalia guianensis and manatee Trichechus manatus) (IBAMA 2019; Magris and Giarrizzo 2020; Soares et al. 2020a, b).

In addition to this threatened fauna, recent research has provided information on the impact of spills on plankton food webs and benthic communities (Campelo et al. 2021; Cerqueira 2021; Craveiro et al. 2021; Gusmão et al. 2021; Lira et al. 2021). During the massive oil spill on the Pernambuco coast (Table 1), the highest percentage of affected zooplankton was recorded in the estuarine plume, followed by the tropical bay and coral reef areas. Traces of ingestion of oil by Brachyura zoea and Calanoida, Paracalanidae, and Oithonidae copepods were observed (Campelo et al. 2021). This analysis also revealed the vulnerability of the larval phases of crabs and scleractinian corals to this spill, indicating that this disaster also affected the recruitment rates in benthic ecosystems. This is highlighted by the important contribution of coral larvae to the reef area, overcoming the copepods, evidencing a spawning event likely due to the reproduction of the endangered Mussismilia harttii (Campelo et al. 2021). This endemic coral is one of the most important reef-building species that underpins the carbonate growth of these unique coral reefs (Miranda et al. 2020). Moreover, the coral endosymbiont Symbiodinium glynnii bioaccumulates oil compounds with concomitant changes in cellular $813 \mathrm{C}$ isotopic values and negative impacts on physiology and growth rate. The induced fitness reduction is inherited by generations, indicating changes of the genetic material, presumably caused by mutagenic PAHs from this extensive oil spill (Müller et al. 2021).

Acute impacts were found on echinoderms (Cerqueira 2021), polychaetes (e.g., Branchiosyllis), and sponges (Craveiro et al. 2021; Lira et al. 2021) with evidence of ingestion of oil stains and droplets. Craveiro et al. (2021) evaluated the effects of the oil spill on algae-associated (Jania capillacea and Penicillus capitatus) communities in shallow-water reefs on the Pernambuco coast. Their results detected a simplification of communities (reduction of species richness and abundance) after oil arrival, while opportunistic and stress-tolerant organisms flourished; for example, the polychaete Branchiomma luctuosum and the isopod Janaira gracilis increased tenfold after the disaster. After two months, the benthic communities restructured to near pre-disaster levels, although polychaete diversity remained low (Craveiro et al. 2021). In this regard, a significant reduction in the polychaete population following the oil spill was found (Lira et al. 2021). The contamination of polychaetes with oil increased mortality, causing a significant reduction in the Branchiosyllis populations associated with the sponge Cinachyrella sp. Another case of simplification of benthic communities was found on the Bahia coast. Gusmao et al. (2021) describe the occurrence of the crustacean Chthamalus bisinuatus colonizing oil stains on intertidal beachrocks one year after the first records. This barnacle was the only sessile benthic suspension feeder on oil stains, and the adult specimens indicate resistance to oil toxicity (Gusmao et al. 2021). Despite these acute impacts registered, Craveiro et al. (2021) highlighted the importance of a more detailed and long-term analysis to evaluate the chronic effects on intertidal rocky reefs.

\section{Socioeconomic impacts}

Preliminary evaluations indicated that at least 869,349 people (365,657 related to tourism and 503,692 artisanal fishers) were affected by this spill (Magris and Giarrizzo 2020) and that traditional fishers were the most impacted social group. Further analysis indicated that there was a significant effect on the seafood trade, including a strong decline in sales and prices. Estevo et al. (2021) argued that sales decreased by 
more than 50\% for all types of fishing on the Alagoas coast, negatively impacting local income generation. The same pattern was observed on the Pernambuco coast by Araújo et al. (2020). They described a decline of at least $60 \%$ in the trade of deep-sea fish species (mackerel, red snapper, and goldfish) and approximately 50\% in cultivated species (salmon and shrimp) compared to previous market prices. Both studies (Araújo et al. 2020; Estevo et al. 2021) were conducted in the Brazilian states highly exposed to the oil spill (Table 1). Although the entire fishing community is affected, collectors of shellfish, oysters, and charru mussels (Araújo et al. 2020) in highly impacted mangrove estuarine areas (Magris and Giarrizzo 2020) felt the consequences more strongly, and since most of these jobs are held by women, this highlights the gender equality impacts induced by this spill.

These traditional human communities, which are already vulnerable to environmental and social risks, have their financial subsistence, food security (e.g., protein provision), public health, and cultural sustainability threatened by the oil spill (Araújo et al. 2020; Pena et al. 2020; Estevo et al. 2021). Fishers interviewed by Estevo et al. (2021) described health impacts, including skin diseases and diarrhea outbreaks after direct oil exposure. Biomonitors and biomarkers are used to evaluate the health effects of environmental degradation from this mysterious oil spill in Brazil (Almeida et al. 2021). Exposure to crude oil likely induced multiple health issues (e.g., lethargy, bristly hair, locomotion difficulty, muscular mass alterations, and changes in weight of the kidneys, liver, and spleen). Furthermore, the exposure resulted in mutagenic damage to bone marrow blood cells and behavioral and morphological alterations, which are usually dose-dependent (Almeida et al. 2021). These results highlight the possible impacts on marine animals and the health of human communities due to the contamination by PAH and toxic metals (Soares et al. 2021). Indeed, due to the absence of coordinated actions by the federal government (Brum et al. 2020; Soares et al. 2020b), fishing colony members collaborated with local communities, NGOs, and universities to remove oil and monitor beaches during the critical periods in several affected regions (Pena et al. 2020). These groups undertook such actions to protect their welfare (Estevo et al. 2021); however, these communityled responses have risked the health of many fishers (Pena et al. 2020) involved in the oil mechanical removal without adequate personal protective equipment (Soares et al. 2020a, b; Estevo et al. 2021).

The most in-depth and large-scale socioeconomic analysis was performed by Câmara et al. (2021). The results of the socioeconomic vulnerability study were mapped; 53,472 establishments, including public institutions, companies, tourist attractions, and leisure points, were included. Among them, the highest impact levels $(30,918)$ were seen in economic sectors related to food
(35.3\%), accommodation (17.4\%), tourism and leisure (3.8\%), shops $(0.7 \%)$, and general services $(0.7 \%)$, which include real estate, travel and tourism services, water transportation, and aquaculture. Finally, establishments with lower vulnerability were supermarkets $(16.9 \%)$, general services (15\%), religious institutions (5.9\%), esthetic services (2.2\%), and automotive services (2.1\%). The state of Bahia was the most socioeconomically affected in the Northeast region, reaching an index $55.6 \%$ higher than the second most affected region (Pernambuco coast). This measurement of the vulnerability index revealed a wide regional variation among the northeastern states. This finding was related to the geographic extension of each state, the effectiveness of actions to fight oil patches, the level of dependence on the blue economy, and social factor deficiencies (Câmara et al. 2021). The socioeconomic vulnerability did not correspond to the areas/states most affected by oil (Table 1), and this pattern indicates that the place where oil arrives and the communities and economic development existing in the affected area are more relevant than the quantity of oil encountered (Soares et al. 2020b). To this effect, Ribeiro et al. (2020) described that the coastal areas of Piauí, Rio Grande do Norte, and Ceará were severely affected in terms of gross domestic product and employment due to activities directly affected by this oil spill, such as fishing and tourism.

In addition, Brazil is the second most affected country (deaths) by COVID-19, with more than 620,000 human deaths, exacerbated by a lack of coordination and denialism by the federal government to act on controlling the pandemic (Castro et al. 2021a, b). In this context, the COVID-19 pandemic aggravated the negative effects of the oil spill since impact analysis and monitoring activities of research groups were halted due to the lockdown decrees (Magalhães et al. 2021). In addition, COVID-19 generated negative cumulative and synergistic impacts on important economic sectors such as hotels, services, and tourism that were already losing revenues because of the oil spill (Câmara et al. 2021; Ribeiro et al. 2020). Another group affected by the combination of the oil spill and COVID-19 were traditional human communities engaged in fishing and shellfish collection that had already faced a decline in seafood consumption during the oil spill (Araújo et al. 2020; Estevo et al. 2021), as they were isolated from the capture and sale of seafood due to COVID-19 (Magalhães et al. 2021). The COVID-19 pandemic should not serve as a justification for the lack of response from the Brazilian government on the origin and impact of oil on the economy, food security, and health of tropical ecosystems, but should serve as a warning for the need to assess cumulative impacts and for the urgent investment in research and environmental policies in the ongoing United Nations Decade of Ocean Science (2021-2030). 


\section{Conclusions and future directions}

In conclusion, this synthetic review article provides up-todate information on this devastating event, one of the worst cases of oil spill impacts worldwide. The affected tropical ecosystems and traditional Brazilian communities should receive strong support in the ongoing years with the midand long-term effects (psychological, ecological, cultural, public health, social, and economic) of oil contamination (Soares et al. 2020a, b; Magalhães et al. 2021). August 2021 marks the two-year somber anniversary of the event and, unfortunately, with no solid responses on the oil origin, proper attention to the socio-environmental damage, and adequate investment in research and public policies to analyze and mitigate impacts. Moreover, this oil spill highlights the latent demand for innovative technical and scientific solutions to problems such as the mysterious case described. The absence of conclusive results on this disaster (see "Oil and source of origin: an unsolved puzzle" section) does not only highlight political and governance weaknesses (Brum et al. 2020; Soares et al. 2020a, b) but also an absence of reliable predictive and integrated modeling tools (Lessa et al. 2021) such as advances in computational modeling tools and remote sensing techniques.

Monitors and co-management measures must be implemented to minimize the public health, ecological, and socioeconomic effects of this extensive spill. To elucidate the magnitude of the disaster and to contribute to the adequate restoration, we emphasize the urgent need for research focusing on the following issues: (1) levels and effects of contamination in tropical food webs; (2) environmental toxicity (PAHs - polycyclic aromatic hydrocarbons) from oil and its residues in populations and ecosystems not evaluated to date (e.g., fishes, oysters, rhodolith beds, and coral reefs) (Miranda et al. 2020; Müller et al. 2021; Soares et al. 2021); (3) biomonitors, biomarkers (Almeida et al. 2021), and microbial remediation of the oil spill (Appolinario et al. 2019; Rodrigues et al. 2020); and (4) monitoring of the acute and chronic ecological and socioeconomic impacts on traditional human communities and coastal ecosystems. Finally, there is a global concern regarding the impacts of mapping, exploitation, transportation, and uses of fossil fuels in the threatened world by climate change and the biodiversity crisis. Biodiversity and climate regulation losses considering blue carbon environments should drive discussions regarding consequences related to new spill events and their global impacts (Soares et al. 2020a, b, c). A global concern should foster a deep discussion regarding the fate of remaining global oil reserves considering the current COP 26 agreements and the urgent decarbonization of the economy.

Acknowledgements We thank the Conselho Nacional de Desenvolvimento Científico e Tecnológico (Research Productivity Fellowship
310165/2020-2, and 313518/2020-3), PELD Costa Semiárida do Brasil-CSB (No. 442337/2020-5), CAPES-PRINT, CAPES-Von Humboldt (AVH), INCT AmbTropic II (CNPq 465634/2014-1), and Fundação Cearense de Apoio ao Desenvolvimento Científico e Tecnológico (Chief Scientist Program) for their financial support. RM Cavalcante thanks CNPq (Research productivity grant, 315281/2020-0) and to the project "Dispersants and adsorbents for remediation of coastal areas affected by crude oil spills (Coast of Ceará, Northeast Brazil) (440868/2020-3).

Author contribution MOS: conceptualization, writing - original draft, writing - review and editing, methodology, formal analysis. CEPT: writing - original draft, writing - review and editing, formal analysis. LEAB: writing - original draft, writing - review and editing, formal analysis. EFR: writing - original draft, writing - review and editing, formal analysis. IBC: writing - original draft, writing - review and editing, formal analysis. RMC: writing - original draft, writing - review and editing, formal analysis. All authors read and approved the final manuscript.

Funding Conselho Nacional de Desenvolvimento Científico e Tecnológico (Nos. 315281/2020-3, 310165/2020-2, and 313518/2020-3), PELD Costa Semiárida do Brasil-CSB (No. 442337/2020-5), CAPESPRINT, CAPES AVH (Alexander Von Humboldt Foundation), INCT AmbTropic II, and Fundação Cearense de Apoio ao Desenvolvimento Científico e Tecnológico (Chief Scientist Program).

Availability of data and materials All data generated or analyzed during this study are included in this published article (and its supplementary information files).

\section{Declarations}

Ethics approval and consent to participate Not applicable.

Consent for publication Not applicable.

Competing interests The authors declare no competing interests.

\section{References}

Almeida KA, Garcia EM, Penteado JO, Tavella RA, Fernandes CLF, Ramires PF, Júnior OVR, Muccillo-Baisch AL, Mathias ML, Dias D, Júnior FMRS (2021) Multimarker approach to assess the exposure of the wild rodent Calomys laucha to a simulated oil spill. Environ Sci Pollut Res 28:2236-2244. https://doi.org/10.1007/ s11356-020-10673-8

Appolinario LR, Tschoeke D, Paixão RVS, Venas T, Calegario G, Leomil L, Silva BS, Thompson CC, Thompson FL (2019) Metagenomics sheds light on the metabolic repertoire of oil-biodegrading microbes of the South Atlantic Ocean. Environ Pollut 249:295-304. https://doi.org/10.1016/j.envpol.2019.03.007

Araújo ME, Ramalho CWN, Melo PW (2020) Artisanal fishers, consumers and the environment: immediate consequences of the oil spill in Pernambuco, Northeast Brazil. Cadernos Saúde Pública 36(1):e00230319. https://doi.org/10.1590/0102-311x00230319

Barbosa LG, Alves MAS, Grelle CEV (2021) Actions against sustainability: dismantling of the environmental policies in Brazil. Land Use Policy 104:105384. https://doi.org/10.1016/j.landusepol. 2021.105384

Beyer J, Trannum HC, Bakke T, Hodson PV, Collier TK (2016) Environmental effects of the Deepwater Horizon oil spill: a review. 
Mar Pollut Bull 110(1):28-51. https://doi.org/10.1016/j.marpo lbul.2016.06.027

Brum HD, Campo-Silva JV, Oliveira EG (2020) Brazil oil spill response: government inaction. Science 367:155-156. https:// doi.org/10.1126/science.aba0369

Câmara SF, Pinto FR, Silva FR, Soares MO, Paula TM (2021) Socioeconomic vulnerability of communities on the Brazilian coast to the largest oil spill (2019-2020) in tropical oceans. Ocean Coast Manag 202:105506. https://doi.org/10.1016/j.ocecoaman.2020. 105506

Campelo RPS, Lima CDM, Santana CS, Silva AJ, Neumann-Leitão S, Ferreira BP, Soares MO, Melo Júnior M, Melo PAM (2021) Oil spill: the invisible impact on the base of tropical marine food webs. Mar Pollut Bull 167:112281. https://doi.org/10.1016/j. marpolbul.2021.112281

Carregosa JC, Santos IRD, Sá MS, Santos JM, Wisniewsi A Jr (2021) Multiple reaction monitoring tool applied in the geochemical investigation of a mysterious oil spill in northeast Brazil. An Acad Bras Cienc 93(4):e20210171. https://doi.org/10.1590/0001-37652 02120210171

Castro IB, Machado FB, Sousa GT, Paz-Villarraga C (2021a) How protected are marine protected areas: a case study of tributylin in Latin America. J Environ Manag 278:111543. https://doi.org/10. 1016/j.jenvman.2020.111543

Castro MC, Kim S, Barberia L, Ribeiro AF, Gurzenda S, Ribeiro KB, Abbott E, Blossom J, Rache B, Singer BH (2021b) Spatiotemporal pattern of COVID-19 spread in Brazil. Science 372:821-826. https://doi.org/10.1126/science.abh1558

Cerqueira WRP (2021) Probable mortality of Holothuria (Halodeima) grisea (Selenka, 1867) (Echinodermata: Holothuroidea) after acute impact of oil spill in the northeast Brazil in 2019. Arq Ciênc Mar 54(1): 61-68. https://doi.org/10.32360/acmar.v54i1.43608

Craveiro N, de Almeida Alves RV, da Silva JM, Vasconcelos E, de Almeida A-J, Rosa Filho JS (2021) Immediate effects of the 2019 oil spill on the macrobenthic fauna associated with macroalgae on the tropical coast of Brazil. Mar Pollut Bull 165:112107. https:// doi.org/10.1016/j.marpolbul.2021.112107

Disner GR, Torres M (2020) The environmental impacts of 2019 oil spill on the Brazilian coast: overview. Rev Bra Gestão Ambient Sustent 7(15): 193-209. https://doi.org/10.21438/rbgas(2020) 071518

Escobar H (2019) Mystery oil spill threatens marine sanctuary in Brazil. Science 366(6466):672-672. https://doi.org/10.1126/science. 366.6466 .672

Estevo MO, Lopes PFM, Oliveira Júnior JGC, Junqueira AB, Santos APO, Lima JA, Malhado ACM, Ladle RJ, Campos-Silva JV (2021) Immediate social and economic impacts of a major oil spill on Brazilian coastal fishing communities. Mar Pollut Bull 164:111984. https://doi.org/10.1016/j.marpolbul.2021.111984

Federal Police (2021) PF conclui investigação e diz que navio grego foi responsável por derramamento de óleo que atingiu litoral brasileiro. Accessed in: https://g1.globo.com/rn/rio-grande-do-norte/ noticia/2021/12/02/pf-conclui-investigacao-e-diz-que-naviogrego-foi-responsavel-por-derramamento-de-oleo-que-atingiulitoral-brasileiro.ghtml

Goncalves LR, Webster DG, Young O, Turra A (2020) The Brazilian Blue Amazon under threat: why has the oil spill continued for so long? Ambient Socied (Online) 23:1-9. https://doi.org/10.1590/ 1809-4422asoc20200077vu202015id

Gusmao JB, Albergaria-Barbosa ACR, Kikuchi RKP, Combi T (2021) The barnacle Chthamalus bissinuatus is the only sessile invertebrate colonizing oil patches on beachrocks one year after a massive oil spill on the Northeastern Brazilian coast. Mar Pollut Bull 173:112952. https://doi.org/10.1016/j.marpolbul.2021.112952

IBAMA (2019) Manchas de òleo no litoral Brasileiro. Available on http://www.ibama.gov.br/manchasdeoleo-fauna-atingida
Johnson DL, Wilson BM, Carr JD, Russell MA, Murphy LE, Conlin DL (2006) Corrosion of steel shipwrecks in the marine environment: USS Arizona-Part 1". Mater Perform 45(10):40-44

Kelvin C, Araújo Matheus C, Barreto Alcides S, Siqueira Anne Caroline P, Freitas Levi G, Oliveira Maria Eugênia PA, Bastos Maria Eduarda P, Rocha Lucimary A, Silva Wallace D, Fragoso (2021) Oil spill in northeastern Brazil: Application of fluorescence spectroscopy and PARAFAC in the analysis of oil-related compounds. Chemosphere 267129154. https://doi.org/10.1016/j.chemosphere. 2020.129154

Landquist H, Hassellöv IM, Rosén L, Lindgren JF, Dahllöf I (2013) Evaluating the needs of risk assessment methods of potentially polluting shipwrecks. J Environ Manag 119:85-92. https://doi. org/10.1016/j.jenvman.2012.12.036

Ladle RJ, Malhado ACM, Campos-Silva JV, Pinheiro BR (2020) Brazil's mystery oil spill: an ongoing social disaster. Nature 578:37. https://doi.org/10.1038/d41586-020-00242-x

Lemos ALM, Bitencourt EC, Santos JGB (2020) Fake news as fake politics: the digital materialities of Youtube misinformation videos about Brazilian oil spill catastrophe. Media Cult Soc. https:// doi.org/10.1177/0163443720977301

Lessa GC, Teixeira CEP, Pereira J, Santos MF (2021) The 2019 Brazilian oil spill: insights on the physics behind the drift. J Mar Syst 222:103586. https://doi.org/10.1016/j.jmarsys.2021.103586

Lira ALO, Craveiro N, Silva FF, Rosa Filho JS (2021) Effects of contact with crude oil and its ingestion by the symbiotic polychaete Branchiosyllis living in sponges (Cinachyrella sp.) following the 2019 oil spill on the tropical coast of Brazil. Sci Total Environ 801:149655. https://doi.org/10.1016/j.scitotenv.2021.149655

Lourenço RA, Combi T, da Rosa AM, Sasaki ST, Zanardi-Lamardo E, Yogui GT (2020) Mysterious oil spill along Brazil's northeast and southeast seaboard (2019-2020): trying to find answers and filling data gaps. Mar Pollut Bull 156:111219. https://doi.org/10. 1016/j.marpolbul.2020.111219

Magalhães KM, Barros KVS, Lima MCS, Rocha-Barreira CA, Filho JSR, Soares MO (2021) Oil spill + COVID-19: a disastrous year for Brazilian seagrass conservation. Sci Total Environ 764:142872. https://doi.org/10.1016/j.scitotenv.2020.142872

Magris RA, Giarrizzo T (2020) Mysterious oil spill in the Atlantic Ocean threatens marine biodiversity and local people in Brazil. Mar Pollut Bull 153:1-3. https://doi.org/10.1016/j.marpolbul. 2020.110961

Mendes LF, Eichler PPB, Leite T, Bennemann ABA, Melo CS, Ferreira AL, Garcia KBL, Silva LLN, Barker CP, Vital H, Gomes MP, Lopes PFM (2021) On the impact of Brazil's largest recent oil spill on regional oceans. Sustain Mar Struct 3(2). https://doi. org/10.36956/sms.v3i2.431

Miranda RJ, Almeida ECG, Pinto TK, Sampaio CLS, Pereira PHC, Nunes JACC, Ladle RJ (2020) Oil spill disaster in Brazil: impact assessment neglecting unique coral reefs. Science. https://science. sciencemag.org/content/366/6466/672/tab-e-letters

Monteiro CB, Oleinik PH, Leal TF, Marques WC, Nicolodi JL, Lopes BCFL (2020) Integrated environmental vulnerability to oil spills in sensitive areas. Environ Pollut 267:115238. https://doi.org/10. 1016/j.envpol.2020.115238

Müller MN, Yogui GT, Gálvez AO, Jannuzzi LGS, Souza Filho JF, Montes MJF, Melo PAMC, Neumann-Leitão S, Zanardi-Lamardo E (2021) Cellular accumulation of crude oil compounds reduces the competitive fitness of the coral symbiont Symbiodinium glynnii. Environ Pollut 289:117938. https://doi.org/10.1016/j.envpol. 2021.117938

Nunes BZ, Zanardi-Lamardo E, Choueri RB, Castro IB (2021) Marine protected areas in Latin America and Caribbean threatened by polyciclic aromatic hydrocarbons. Environ Pollut 269:116194. https://doi.org/10.1016/j.envpol.2020.116194 
Rodrigues EM, Cesar DE, Oliveira RS, Siqueira TP, Tótola MR (2020) Hydrocarbonoclastic bacterial species growing on hexadecane: implications for bioaugmentation in marine ecosystems. Environ Pollut 267:115579. https://doi.org/10.1016/j.envpol.2020.115579

Sissini MN, Berchez F, Hall-Spencer J, Ghilardi-Lopes N, Carvalho VF, Schubert N, Koerich G, Diaz-Pulido G, Silva J, Serrão E, Assis J, Santos R, Floeter SR, Rörig L, Barufi JB, Bernardino AF, Francini-Filho R, Turra A, Hofmann LC, Aguirre J, Le Gall L, Peña V, Nash MC, Rossi S, Soares M, Pereira-Filho G, Tâmega F, Horta PA (2020) Brazil oil spill response: protect rhodolith beds. Science 367(6474):156-156. https://doi.org/10.1126/scien ce.aba2582

Oliveira OMC, Queiroz AFS, Cerqueira JR, Soares SAR, Garcia KS, Filho AP, Rosa MLS, Suzart CM, Pinheiro LL, Moreira ITA (2020) Environmental disaster in the northeast coast of Brazil: forensic geochemistry in the identification of the source of the oily material. Mar Pollut Bull 160:111597. https://doi.org/10.1016/j. marpolbul.2020.111597

Pena PGL, Northcross AL, Lima MAG, Rêgo RCF (2020) The crude oil spill on the Brazilian coast in 2019: the question of public health emergency. Cad Saude Publ 36(2):e00231019. https://doi. org/10.1590/0102-311x00231019

Rajendran S, Vethamony P, Sadooni FN, Al-Kuwari HA, Al-Khayat JA, Seegobin VO, Govil H, Nasir S (2021) Detection of Wakashio oil spill off Mauritius using Sentinel-1 and 2 data: capability of sensors, image transformation methods and mapping. Environ Pollut 274:116618. https://doi.org/10.1016/j.envpol.2021.116618

Ribeiro LCS, Souza KB, Domingues EP, Magalhães AS (2020) Blue water turns black: economic impact of oil spill on tourism and fishing in Brazilian Northeast. Curr Issue Tour. https://doi.org/ 10.1080/13683500.2020.1760222

Soares MO, Teixeira CEP, Bezerra LEA, Rossi S, Tavares T, Cavalcante RM (2020a) Brazil oil spill response: time for coordination. Science 367(6474):155-155. https://doi.org/10.1126/scien ce.aaz9993
Soares MO, Teixeira CEP, Bezerra LEA, Paiva SV, Tavares TCL, Garcia TM, Araujo JT, Campos CC, Ferreira SMC, Matthews-Cascon H, Frota A, Mont'Alverne TCF, Silva ST, Rabelo EF, Barroso CX, Freitas JEP, Melo-Junior M, Campelo RPS, Santana CS, Carneiro PBM, Meirelles AJ, Santos BA, Oliveira AHB, Horta P, Cavalcante RM (2020b) Oil spill in South Atlantic (Brazil): environmental and governamental disaster. Mar Policy 115:103879. https://doi.org/10.1016/j.marpol.2020.103879

Soares MO, Salani S, Paiva SV, Braga MDA (2020c) Shipwrecks help invasive coral to expand range in the Atlantic Ocean. Mar Pollut Bull 158:111394. https://doi.org/10.1016/j.marpolbul.2020. 111394

Soares EC, Bispo MD, Vasconcelos VC, Soletti JI, Carvalho SHV, Oliveira MJ, Santos MC, Freire ES, Nogueira ASP, Cunha FAS, Sandes RDD, Santos RAR, Neta MTSL, Narain N, Garcia CAB, Costa SSL, Santos JCC (2021) Oil impact on the enviroment and aquatic organisms on the coasts of the states of Alagoas and Sergipe, Brazil - a preliminary evaluation. Mar Pollut Bull 171:112723. https://doi.org/10.1016/j.marpolbul.2021.112723

Ventikos NP, Louzis K, Koimtzoglou A (2013) The shipwrecks in Greece are going fuzzy: a study for the potential of oil pollution from shipwrecks in Greek waters. Human Ecol Risk Assess 19:462-491. https://doi.org/10.1080/10807039.2012.713820

Zacharias DC, Gama CM, Fornaro A (2021a) Mysterious oil spill on Brazilian coast: analysis and estimates. Mar Pollut Bull 165:112125. https://doi.org/10.1016/j.marpolbul.2021.112125

Zacharias DC, Gama CM, Harari J, Rocha RP, Fornaro A (2021b) Mysterious oil spill on the Brazilian coast - part 2: a probabilistic approach to fill gaps of uncertainties. Mar Pollut Bull 173:113085. https://doi.org/10.1016/j.marpolbul.2021.113085

Publisher's Note Springer Nature remains neutral with regard to jurisdictional claims in published maps and institutional affiliations. 